\title{
Thermal Management of Fuel Cell-driven Vehicles using HT-PEM and Hydrogen Storage
}

\author{
Mounir Nasri \\ German Aerospace Center (DLR) \\ Institute of Vehicle Concepts \\ Pfaffenwaldring 38-40, 70569 \\ Stuttgart, Germany \\ Email: Mounir.Nasri@dlr.de
}

\author{
Dave Dickinson \\ German Aerospace Center (DLR) \\ Institute of Vehicle Concepts \\ Pfaffenwaldring 38-40, 70569 \\ Stuttgart, Germany \\ Email: Dave.Dickinson@dlr.de
}

\begin{abstract}
A battery electric vehicle equipped with a range extender is a suitable solution for both urban and long-distance traffic. Compared with the internal combustion engine-powered range extender the fuel cell range extender is a zero emission solution and has been investigated for many years. In this work a system for hydrogen storage for the heating and cooling of a high temperature polymer membrane fuel cell range extender itself using a metal-hydride storage tank [1] is investigated. In order to survey the suitability of this system for electric vehicles, an overall vehicle simulation model using the AlternativeVehicles library [2] is developed.

Taking into consideration the challenges that are now placed on modern cars, several scenarios such as cold start and normal operation are created. For these scenarios suitable operating strategies are developed and integrated into the overall vehicle model. Based on various driving cycles the thermal and electrical behavior of the thermally coupled high temperature polymer membrane fuel cell and the metal-hydride storage tank is investigated.
\end{abstract}

Keywords-range extender; fuel cell; thermal management; operating strategies; electric vehicle; metal-hydride storage.

\section{INTRODUCTION}

In the near future, battery electric vehicles with a fuel cell range extender are expected to be introduced with a large scale in the city transportation networks, in an attempt to reduce the air pollution and to increase the range. For such range extenders, high temperature polymer membrane fuel cell (HT-PEM) is presently considered as an attractive candidate, as it exhibits better cooling behavior compared to the low temperature PEM. The high operating temperature of the HT-PEM fuel cell is advantageous for the better heat dissipation. But the system needs higher heat energy to rise the fuel cell temperature up to its operating point.
The Institute of Vehicle Concepts of the German Aerospace Centre (DLR) is developing a HT-PEM fuel cell range extender for the smart fortwo electric car [3]. In order to heat up and cool down the fuel cell a new thermal management system for the HT-PEM fuel cell range extender will be presented. The idea is to use a metalhydride storage to store hydrogen and to support the fuel cell heating as well as the cooling if it is needed.

Based on existing component models a thermal simulation model of the high temperature coolant circuit including the HT-PEM fuel cell and the metal-hydride storage tank is build using the AlternativeVehicles library [2]. This thermal model is then implemented into an electrical and mechanical vehicle model. Moreover, suitable operating strategies are developed and integrated into the overall vehicle model, which will be tested by the use of different driving cycles such as the NEDC (New European Driving Cycle) [4] and the Artemis-Motorway cycle (Assessment and Reliability of Transport Emission Models and Inventory Systems) [5].

\section{MODELLING OF THE COMPONENTS FOR THE HT-PEM FUEL CELL RANGEEXTENDER}

\section{A. The fuel cell}

The fuel cell system consists of a single module with 120 cells. The cells are connected in series and produce a maximum current of $130 \mathrm{~A}$. The fuel cell is based on a high temperature PEM stack and generates a rated net power of $6 \mathrm{~kW}$ on pure hydrogen. The fuel cell can be cooled with a radiator or a liquid/liquid heat exchanger, as shown in figure 1[6].

The fuel cell manufacturer, Serenergy, suggest using Triethylene glycol (TEG) or Propyl alcohol as a coolant because of the high operation temperature up to $180{ }^{\circ} \mathrm{C}$. 


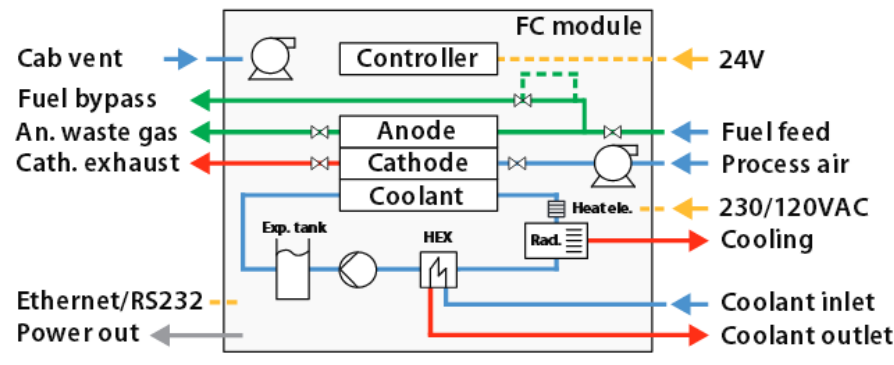

Fig. 1: Layout of the Serenus 25/65/120: The liquid cooled fuel cell modul from Serenergy [6]

A map-based model is used for the modeling of the HT-PEM fuel cell. This model is suitable for system simulation, where a high simulation speed and detailed results are required [2]. In order to parameterize the model, the polarization curve is taken from the data sheets of the liquid cooled fuel cell module [6].

The specification of the thermal mass is of great importance for the thermal simulation. This parameter presents the product of the fuel cell mass and the related thermal capacity. Depending on the power loss as well as the thermal mass, the fuel cell temperature changes, whereas the power loss present the thermal dissipation of the fuel cell and is proportional to the voltage difference of the open-circuit voltage $\left(U_{0}\right)$ and the actual voltage $\left(U_{\text {Stack }}\right)$. The power loss $P_{\text {loss }}$ is calculated as follows:

$$
P_{\text {loss }}=\left(\mathrm{N} * U_{0}-U_{\text {Stack }}\right) * I
$$

Where $\mathrm{N}$ is the number of cells, $U_{0}$ is equal to $1.23 \mathrm{~V}$ and $I$ is the actual current

\section{B. Metal-hydride hydrogen storage}

The hydrogen storage model is a zero dimensional (0D) dymola model and is based on the equilibrium reactions [7]. The mass balance is described by the following equations:

$$
\frac{1}{R T} \frac{\partial p}{\partial t}-\frac{p}{R T^{2}} \frac{\partial T}{\partial t}+\frac{\dot{n}}{\pi\left(R_{o}^{2}-R_{i}^{2}\right) L}+\frac{1-\varepsilon}{\varepsilon} \frac{\rho_{s}}{2 M M H} \frac{\partial q}{\partial t}=0
$$

where $p$ is the pressure in the reaction bed, $T$ the mean hydrogen temperature in the metal hydride bed, $R$ the universal gas constant, $n$ the hydrogen flow rate, $R_{i}$ the inner radius, $R_{o}$ the outer radius, $L$ the length of the reaction bed, $\varepsilon$ the porosity of the metal hydride bed, $\rho_{s}$ the density of the metal hydride, $M M H$ the average molecular mass of the metal hydride and $q$ the hydrogen concentration.

The corresponding energy balance, ignoring convection effects (as it contains no spatial gradients), is written as:

$$
\begin{aligned}
& \left(\frac{p}{R T} C_{p H_{2}}+\frac{1-\varepsilon}{\varepsilon} \rho_{s} C_{p S}\right) \frac{\partial T}{\partial t}+\frac{\partial p}{\partial t}+\frac{1-\varepsilon}{\varepsilon} \frac{\rho_{s} \Delta H}{2 M M H} \frac{\partial q}{\partial t}+ \\
& \left(T-T_{m}\right) \frac{2 h_{b e d} R_{i}}{\varepsilon\left(R_{o}^{2}-R_{i}^{2}\right) L}=0,
\end{aligned}
$$

where $C_{p H 2}$ is the heat capacity of hydrogen, $C_{p S}$ is the heat capacity of the metal hydride, $\Delta H$ is the isosteric heat of adsorption of the hydrogen in the metal hydride, $h_{\text {bed }}$ is the overall heat transfer coefficient between the coolant and the metal hydride bed and $T_{m}$ is the temperature of the coolant.

The hydrogen storage can be scaled by adjusting the geometrical dimensions which are the length and the radius of the metal-hydride bed.

\section{THERMAL MODEL}

For the overall system simulation a thermal model of the cooling system for the range extender is developed. As can be seen in figure 2, the model comprises two coolant circuits: the low (LT) and high (HT) temperature coolant circuit. The LT coolant circuit is responsible for the continuous temperature equalization of the battery and power electronics as well as the cooling of the electric motor. The HT coolant circuit is however responsible for the heating and cooling of the HT-PEM fuel cell. As the innovation lies in the temperature control of the HT-PEM fuel cell using a metal-hydride storage tank, only the HT coolant circuit model will be presented here. This model consists of a metal-hydride hydrogen storage system and a proton exchange membrane (PEM) fuel cell stack which are thermally coupled by a high temperature coolant circuit. The hydrogen decomposition in the metal-hydride bed occurs at a coolant temperature above $110^{\circ} \mathrm{C}$ and therefore, a HT-PEM fuel cell is needed for the coupling. The high operating temperatures of the HT-PEM fuel cell which ranges between $100^{\circ} \mathrm{C}$ and $160^{\circ} \mathrm{C}$ are needed in order to access the full potential of the metal hydride storage system. In addition to the above-mentioned components, the HT cooling circuit includes pipes, pumps, a high temperature radiator and a heat exchanger for the passenger compartment, as shown in figure 2.

The heat supplied by the HT-PEM was assumed to be transferred to the storage tanks by a coolant cycle. As coolant Ucotherm S-15 A is used. Ucotherm is a waterfree synthetic oil, but water-soluble heat transfer fluid and is specifically used for temperatures between $100^{\circ} \mathrm{C}$ and $205^{\circ} \mathrm{C}$. Due to its high viscosity index and excellent low temperature fluidity, Ucotherm is used for even lower ambient temperatures [8]. 


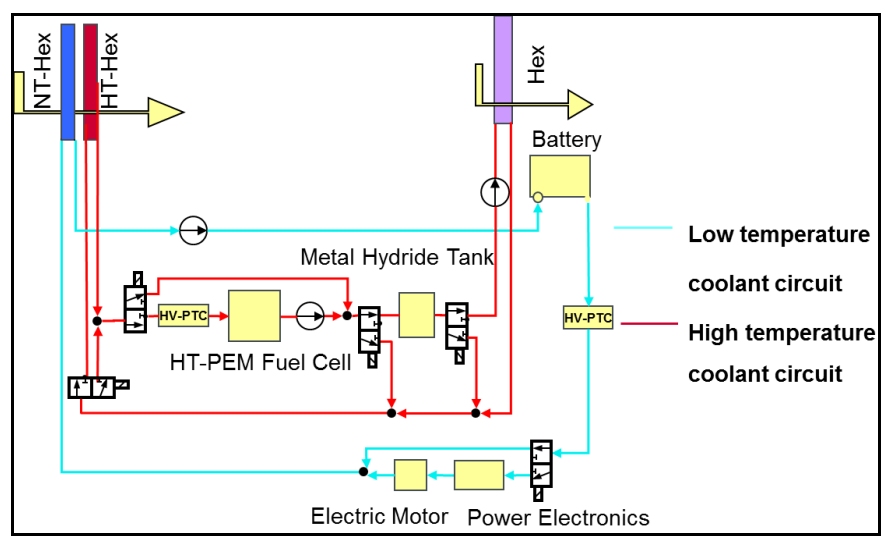

Fig. 2: Layout of the low (blue) and high (red) temperature coolant circuit in a battery electric vehicle with a high temperature fuel cell range extender

\section{OPERATING STRATEGIES AND THERMAL CONTROLLER}

In order to integrate the thermal model into the overall vehicle model, a thermal controller must be developed. The controller outputs are carried out on the difference between the desired operation point (setpoint) and the current operation point (measured). For this purpose operation strategies will be developed which take into account several operational scenarios such as cold start, normal operation and step-change in the fuel cell performance.

\section{A. Cold start}

In the start phase, first the temperature of the fuel cell is increased up to $100{ }^{\circ} \mathrm{C}$ in order to obtain the minimum operation temperature level of the FC. Therefore, only the preheater (e.g., PTC heater) and the fuel cell are thermally coupled by the oil circuit. After that, the valve downstream from the FC is opened allowing the heat of the metal-hydride storage to activate the hydrogen desorption. Since the fuel cell is not active and thus no hydrogen is consumed, the pressure in the tank increases, as shown in figure 3 . When the hydrogen pressure inside the tank reaches 10 bars, the PTC heater is switched off and both components, the fuel cell as well as the storage tank, will be thermally coupled. The storage provides the fuel cell with hydrogen by absorbing the fuel cell waste heat.

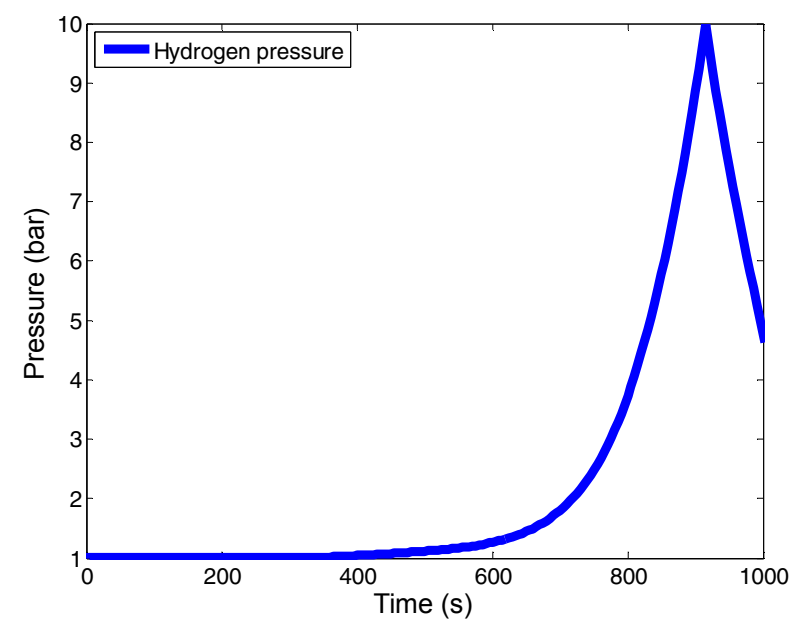

Fig. 3: Gas phase pressure inside the metal hydride bed during cold start operation and while thermally coupled and uncoupled to the fuel cell.

As can be seen in Figure 4, it takes about 6 minutes (360 s) until the fuel cell temperature reaches $100^{\circ} \mathrm{C}$ if a $6 \mathrm{~kW}$ PTC heater is used and the start temperature is equal to $20{ }^{\circ} \mathrm{C}$. The heating of The Serenergy HT-PEM with a stack mass of $21 \mathrm{~kg}$ and a thermal capacity of around $900 \mathrm{~J} / \mathrm{kg} \mathrm{K}$ from $20{ }^{\circ} \mathrm{C}$ to $100^{\circ} \mathrm{C}$ depends on the heating power and ca be decreased if the heating power is higher than $6 \mathrm{~kW}$.
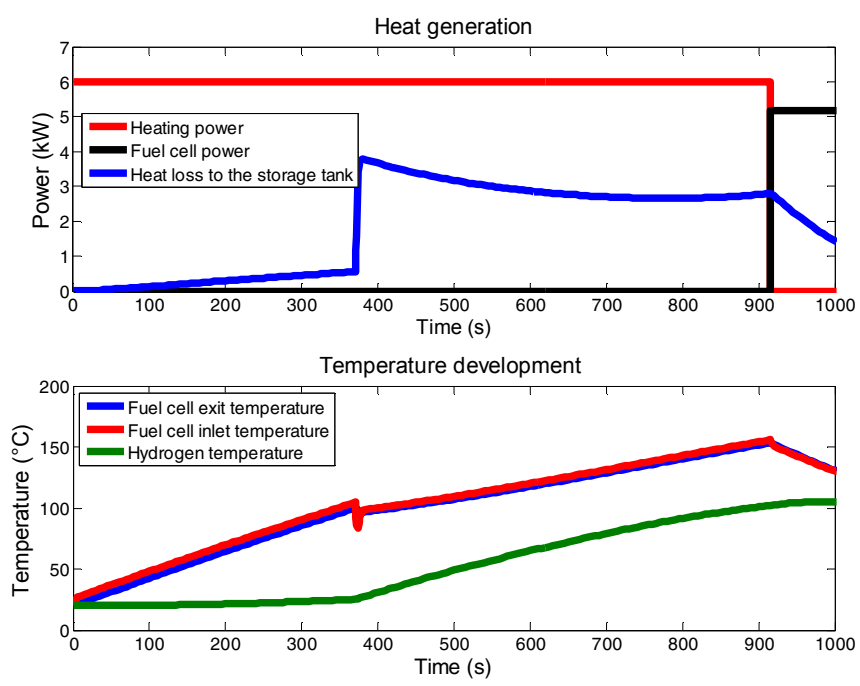

Fig. 4: Prediction of the temperature development of the coolant and the heat generation during the start-up phase

\section{B. Normal operation}

The main task in the normal operation phase is to keep the temperature of the fuel cell in the operating range recommended by the manufacturer $\left(100^{\circ} \mathrm{C}\right.$ $\left.160^{\circ} \mathrm{C}\right)$. In order to ensure that the upper temperature limit of $160{ }^{\circ} \mathrm{C}$ is not exceeded, the thermostat (the valve 
placed before the main heat exchanger in figure 2) is opened, so that the high temperature cooler is included in the coolant circuit and the excess heat can be dissipated to the outside air. Alternatively, this heat can be used for the heating of the passenger compartment.

The air mass flow through the high temperature radiator is regulated such that the coolant inlet temperature for the fuel cell is equal to $160^{\circ} \mathrm{C}$. Figure 5 shows the temperature development of the coolant at the inlet and outlet of the FC during the Artemis-Motorway cycle. It can be seen that after about 9 minutes the fuel cell temperature reaches $150^{\circ} \mathrm{C}$ by the use of $6 \mathrm{~kW}$ PTC heater. When the range extender is activated, the fuel cell temperature increases up to approx. $160{ }^{\circ} \mathrm{C}$ and after about 16 minutes the HT heat exchanger is used to dissipate the excess heat to the outside air.

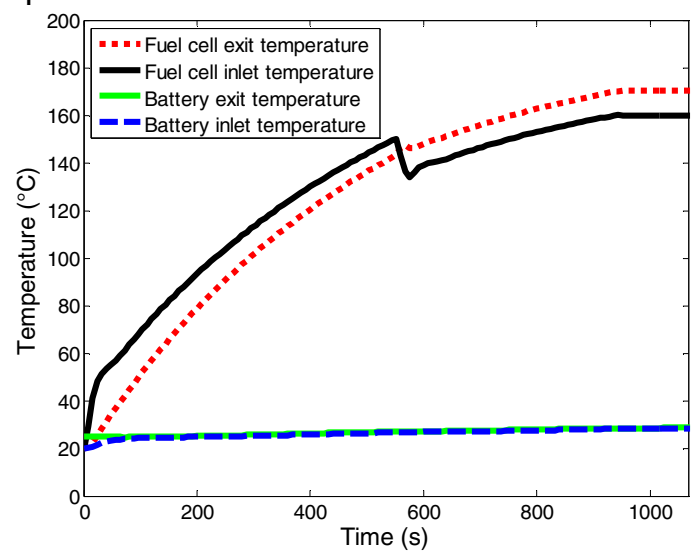

Fig. 5: Prediction of the temperature development of the coolant at the inlet and outlet of the FC during the Artemis-Motorway cycle

The coolant mass flow for the fuel cell is determined such that the temperature difference of the coolant at inlet und outlet of the fuel cell is equal to $10{ }^{\circ} \mathrm{C}$, as shown in figure 5.

\section{Step-change in the fuel cell performance}

The upper diagram of figure 6 shows that with a storage capacity of approximately $0.012 \mathrm{~m}^{3}$ the ArtemisMotorway simulation is stopped after 11 minutes, because the pressure of the gaseous hydrogen is too low, so that the metal-hydride storage tank is unable to supply the fuel cell with the needed hydrogen mass flow. If the tank volume is increased to $0.02 \mathrm{~m}^{3}$, the metal-hydride storage tank releases enough hydrogen, so that the Artemis-Motorway cycle is successfully simulated.
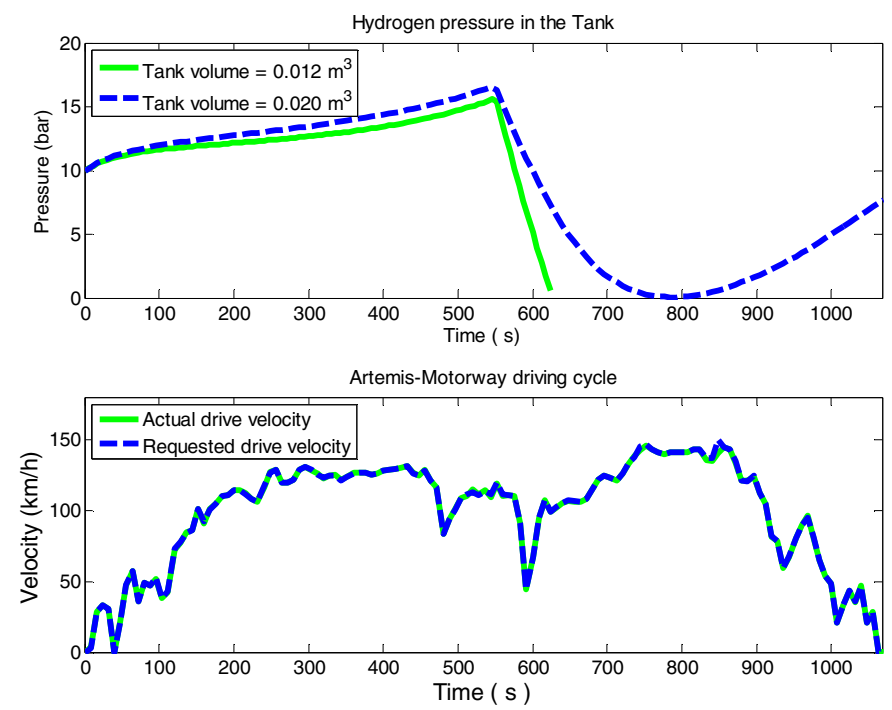

Fig. 6: Pressure progression during the Artemis-Motorway cycle for different metal-hydride storage tanks

\section{SYSTEM SIMULATION AND RESULTS}

Figure 7 shows the overall vehicle model which includes three subsystems:

- the powertrain model,

- the thermal model,

- the controller module.

1) Powertrain model: Based on the AlternativeVehicles library [2] a model of the powetrain is developed. It includes the models of the battery, electrical drive, power electronics and chassis including the longitudinal dynamics of the vehicle.

2) Thermal model: It consists of the low temperature coolant circuit for the battery, power electronics and electric motor as well as the high temperature coolant circuit for the HT-PEM fuel cell and the metal-hydrides storage tank.

3) Controller module: It includes the control strategies for the energy and thermal management.

The table 1 summarizes the vehicle data which is used for the model parameterization. The vehicle mass is about $980 \mathrm{~kg}$. Its battery has a storage capacity of $17.6 \mathrm{kWh}$ and the maximum motor power is around $55 \mathrm{~kW}[3]$. 


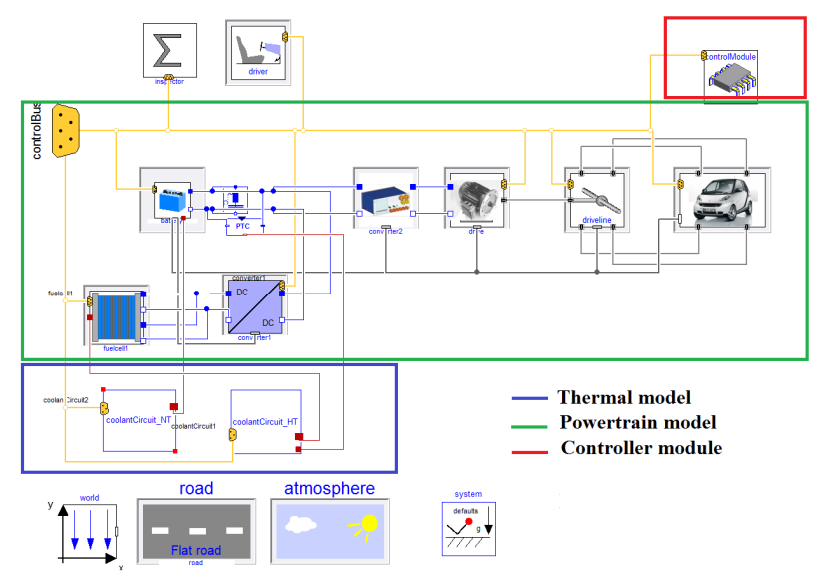

Fig. 7: The overall vehicle model implemented in Dymola/Modelica

TABLE 1: VEHICLE DATA USED FOR THE MODEL PARAMETERIZATION

\begin{tabular}{|c|c|}
\hline Parameter & Value \\
\hline Vehicle mass in kg [3] & 980 \\
\hline Battery mass in kg [9] & 174 \\
\hline Battery capacity in kWh [3] & 17.6 \\
\hline $\begin{array}{c}\text { Max. power electric motor in } \\
\mathrm{kW}[3]\end{array}$ & 55 \\
\hline Wheelbase in mm [3] & 1,867 \\
\hline $\begin{array}{c}\text { Coefficient of drive resistance } \\
\text { polynomial [9] }\end{array}$ & {$[0.4224,1.222,77.888]$} \\
\hline
\end{tabular}

To analyze the energy demand of the range extender as well as the thermal system behavior the simulation results of the NEDC cycle is taken as an example. It is observed from figure 8 that the actual velocity corresponds to the target velocity during the whole NEDC cycle. In figure 9, the energy demand and heat loss of the battery as well as the HT-PEM fuel cell during the NEDC are plotted. It is clear that the fuel cell is used as a range extender and delivers $6 \mathrm{~kW}$ to charge the battery or to drive the vehicle depending on the target velocity and the actual operation point. In order to achieve the desired velocity of $120 \mathrm{~km} / \mathrm{h}$ at the end of the cycle, the battery provides $38 \mathrm{~kW}$ when the fuel cell is switched on. The heat loss of the fuel cell is slightly higher than the electric power because of an averaged efficiency factor of about $48 \%$.

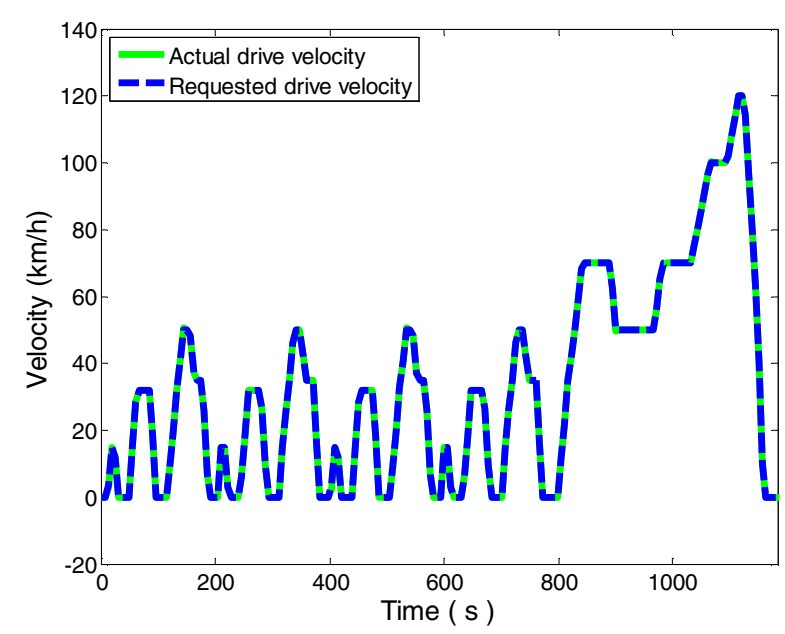

Fig. 8: The NEDC velocity profile

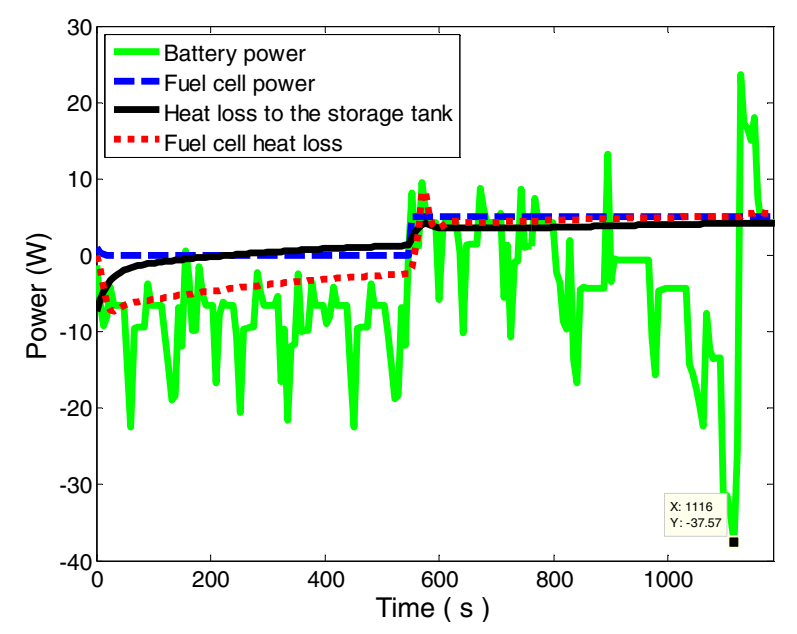

Fig. 9: The energy demand and heat loss of the battery as well as the HT-PEM fuel cell during the NEDC

Figure 10 shows the coolant inlet and outlet temperature of the fuel cell system versus time. It is obvious that the temperature of the fuel cell is kept in the operating range recommended by the manufacturer (e.g., between $100{ }^{\circ} \mathrm{C}$ and $160^{\circ} \mathrm{C}$ ) and the fuel cell inlet temperature is lower than $160{ }^{\circ} \mathrm{C}$ during the whole NEDC cycle. 


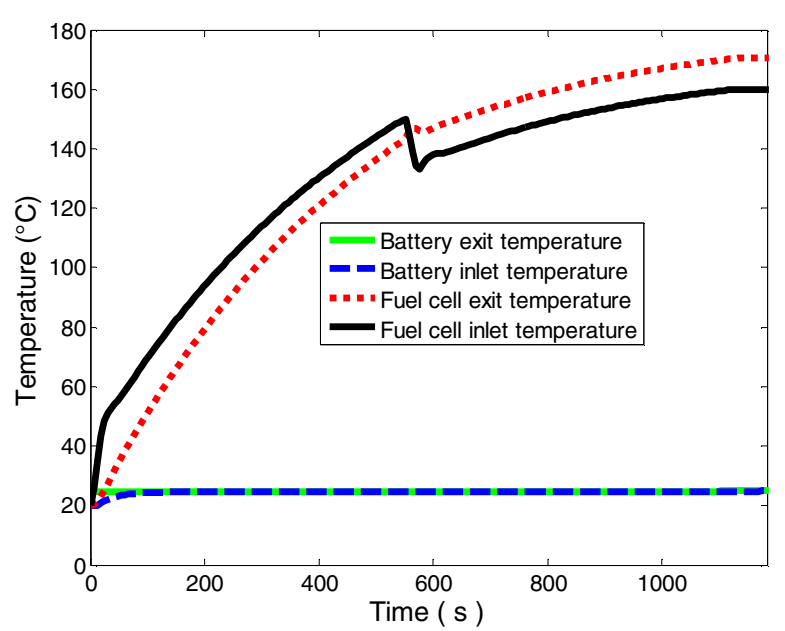

Fig. 10: Prediction of the temperature development of the hydrogen inside the tank and the coolant at the inlet and outlet of the FC during the NEDC cycle

\section{CONCLUSION.}

The paper was aimed at the development of an innovative thermal management system for a battery electric vehicle which uses high temperature polymer membrane fuel cell as range extender. This system is based on thermally coupled fuel cell and metal-hydrides storage tank which sustains the fuel cell cooling and the hydrogen storage.

Using the AlternativeVehicles library developed by The Institute of Vehicle Concepts (DLR), a thermal model of the thermally coupled HT-PEM fuel cell and metal-hydrides storage Tank was created. Moreover, an appropriate thermal controller was modeled based on several scenarios for electric car operation such as cold start up and normal operation. Both models were integrated into an overall vehicle model. Various driving cycles was used to determine the thermal system behavior as well as the energy demand of the individual range extender components. It was shown that the starting temperatures, i.e. the pre-heating before starting fuel cell operation and the tank volume, were found to have a considerable influence on operation time because of the possible break-down of hydrogen pressure in the tank. In addition, the developed thermal management system is able to cool down the fuel cell and, at the same time, to release the hydrogen required for the fuel cell during the whole NEDC cycle.

Since the operating strategy strongly depends on the cabin air-conditioning, it is planned in the next work to create a model of the passenger comportment and to integrate it into the overall vehicle model.

\section{REFERENCES}

[1] P. Pfeifer and C. Wall et al., Thermal coupling of a high temperature PEM fuel cell with a complex hydride tank, International Journal of Hydrogen Energy 34, pp. 3457-3466, 2009.

[2] J. Ungethüm and D. Hülsebusch and H. Dittus and T. Braig, Simulation of alternative powertrains in Modelica, ASIM Conference, Ulm, 2010.

[3] Daimler AG, Simply electric. smart fortwo electric drive, ebrochure, 2013.

[4] EU commission, The Official Journal of the European Union, UN/ECE-R 83, Brussels, 2012.

[5] M. Andre, Real-world driving cycles for measuring cars pollutant emissions-Part A: The ARTEMIS European driving cycles, Bron, June 2004.

[6] Serenergy, Fuel Cell Stack Module Senerus Liquid C, Datasheet, v $1.0-0213$.

[7] Z. Jianga and R.A. Dougala et al., Simulation of a thermally coupled metal-hydride hydrogenstorage and fuel cell system, Journal of Power Sources 142, pp. 92-102, 2005.

[8] Fragol Schmierstoff $\mathrm{GmbH} \&$ Co. KG, Thermal oil UCOTHERM, Datasheet, 2013.

[9] D. Dickinson and M. Nasri, Range Extender Vehicle Concept Based on High Temperature Polymer Electrolyte Membrane Fuel Cell, EVER 14, Monaco, March 2014 